\title{
Aspects related to the interconnection between music and the human brain. Scientific discoveries and contemporary challenges
}

\author{
ROSINA CATERINA FILIMON, Lecturer, $\mathrm{PhD}$ \\ "George Enescu" National University of the Arts Iași \\ ROMANIA*
}

Motto:

"If a tree falls in the forest and there is no one there to hear it, does it make a sound or not?"

George Berkeley

\begin{abstract}
A new scientific discipline, neuromusicology, connects the scientific research of music and that of the nervous system, in particular of the brain. It studies the effects of music on the brain; the present paper relates to this particular field. Initially, the right hemisphere was associated with the process of music reception and it was considered that the activation of the left hemisphere was the responsibility of language. Neuroimaging, however, demonstrates that the elements of musical language activate various brain areas in both hemispheres, simultaneously generating the perception of music and emotions. Research in the field of psychoacoustics has revealed that listening to music triggers the production of neurotransmitters in the body that relieve pain, reduce stress and anxiety. Another effect determined by listening and studying music is the structural changes that occur at brain level due to brain neuroplasticity. Pathological changes at brain level have consequences in perception and influence all human activities. Disease alters the artistic creativity of people suffering from various pathologies, biographies of many artists proving that neurological diseases influenced their artistic activity. Decoding the functioning of the brain in the presence of music and its effects on brain activity make it possible to use music therapy as a complementary method to medical treatment. The harmful effects of the current Covid-19 pandemic on the brain are obvious and are already reported in completed or ongoing research studies. The adoption of music as a therapeutic tool in the current global epidemiological crisis highlights its undeniable qualities in multiple pathologies and updates its mental and somatic benefits, complementary to medicine. All this provides an important drive in the reassessment and reconfiguration of the need to amplify the interference strategies between the field of music and that of medicine, implicitly that of neurology.
\end{abstract}

Keywords: neuromusicology, cerebral hemispheres, neuroplasticity, music therapy, Covid-19 pandemic.

\footnotetext{
*rosinafilimon@yahoo.com
} 


\section{Introductory. The cerebral hemispheres and music}

A new scientific discipline, neuromusicology, connects the scientific research of music and that of the nervous system, in particular of the brain. It studies the effects of music on the brain; the present paper relates to this particular field.

What we define as music actually represents the mental content generated by our brain in response to external vibrating stimuli that cause musical reception and perception. In point of fact, the musical piece we hear is matter that vibrates outside us and stimulates the brain causing various sensations. The brain is defined as "a sophisticated learning system; in fact, it generated true and genuine sounds from external vibrations; this is true for both spoken language and sound and for the music produced by musical instruments. Outside us there are no sounds and noises, as they are a cerebral response determined by the vibrations of the outer world" (Manzelli, 2003). Starting from this definition, the answer to the following question, phrased by Irish philosopher George Berkeley (1685-1753), becomes obvious: "if a tree falls in the forest and there is no one there to hear, does it make a sound or not? [...] The answer is no - sound is a mental image created by the brain in response to the vibration of molecules" (Levitin, 2010, p. 29).

Pleasant or unpleasant music exists only in the subjective way in which the listener perceives and analyses a musical piece. Our aesthetic sensations, the mental imagery we associate with a particular piece of music is the result of a mental musical content, specific to each individual, which depends on many factors: the listener's education and training, the encoding, storage and retrieval ability of memorised information, psychosomatic reactivity, the level of concentration, the age of the user, other factors such as the geographical or historical element, or the individual's inclination towards a particular field, in the case of both the amateur and the musician. As each individual is unique from a cerebral and psychic point of view, it has its own personal way of reacting to external stimuli, thus living a more or less different experience on listening to a musical piece. Objective and absolute judgments on a musical piece cannot be expressed, there is no reference version of it, in fact there are as many variants as there are listeners. "Even the researcher's objectivity depends on the degree of 'expectation' (experience) that the environment, education, the historical moment with all its procession of taboos of acceptance or rejection has unconsciously formed in him/her." (Gaspar, 2002, p. 11)

The brain ${ }^{1}$, the coordinator of the whole organism, processes and stores the information transmitted by the sense organs, much like a computer, and transmits motor impulses to the muscular and endocrine systems. The seat of

\footnotetext{
${ }^{1}$ The brain or encephalon consists of the cerebral hemispheres, diencephalon, cerebellum and brainstem.
} 
perceptual, motor, cognitive functions, including memory and emotionality, is in the cerebral hemispheres. Even though the two cerebral hemispheres appear to be identical, there are functionally essential differences between them, as each of them specializes in certain mental processes. They are connected by a bridge made up of a bundle of nerve fibres, a transverse commissure called corpus callosum. If this bridge is fractured (split brain), the cerebral hemispheres will behave differently. The split brain phenomenon was experimented on by Roger Wolcott Sperry (1913-1994), a physician, neuropsychologist, neurobiologist, one of the most important scientists of the twentieth century, who made the understanding of the lateralization of brain functions possible. The research was initially conducted with the therapeutic purpose of treating epilepsy (1959-1968). Sperry surgically sectioned the corpus callosum (the area of the brain that connects the right hemisphere to the left hemisphere) and, following neuropsychological tests, observed that the cerebral hemispheres of patients operated on for callosotomy show specific functions. Sperry was awarded the Nobel Prize in Physiology or Medicine (1981) for this discovery (Tramo, 2009) (Pearce, 2019, pp. 217-220).

Each of the two cerebral hemispheres commands and perceives sensations from the opposite side of the body: the right hemisphere coordinates the information coming from the left side of the body, while the left hemisphere coordinates those from the right side. Each cerebral hemisphere specializes in certain mental activities and comprises four lobes: frontal, parietal, temporal and occipital. The frontal lobe is the seat of voluntary movements, and the lesions of this lobe cause motor disorders (paralysis), disorders in the correct articulation of words (dysarthria, anarthria), behavioural disorders. At the level of the parietal lobe, all types of sensitivity are synthesized, as it is the cortical seat of the general sensitivity analyser. This lobe involves sensation and perception; damage to this area causes audio-visual impairments, incapacity to recognize objects by touch (tactile agnosia), problems in the appreciation of the physical properties of objects, volume and shape (stereognosis). The temporal lobe is the cortical seat of the auditory analyser. Lesions to this lobe lead to verbal deafness, in which the patient hears, but is unable to comprehend, to auditory hallucinations, balance disorders, apraxia - the inability to use objects and perform usual gestures; sensory aphasia, in which the understanding of the meaning of spoken or written words is lost. The occipital lobe is the seat of the cortical end of the visual analyser (primary visual cortex). Lesions to this analyser lead to spatial disorientation, as well as visual impairment (Beaumont, 2008) (Rouse, 2019). "However, it is increasingly clear that cognitive functions cannot be assigned exactly to points on the brain, like cities on a map. An assigned mental task can involve a complicated network of circuits that interact, more or less, with others from all over the brain - not like the components of a machine, but rather 
like the instruments in a symphony orchestra, which combine pitch, volume and timbre to create a special musical effect." (Shreeve, 2005, pp. 20-21)

Recent research carried out with the help of medical devices for noninvasive neuro-imaging - magnetic resonance imaging (MRI), and positron emission tomography (PET) - allow viewing the reaction of the brain, triggered by a stimulus, through the observation of the increase in blood flow to a certain area of the brain, which reveals the amplification of the electrical activity in the brain involving areas that are in charge of various functions. Initially, the right hemisphere was associated with the process of music reception and it was considered that the activation of the left hemisphere was the responsibility of language. Neuroimaging, however, demonstrates that the elements of musical language activate various brain areas in both hemispheres, simultaneously generating the perception of music and emotions. Timbre and melody are received by the right brain hemisphere, which is creative; the sound rhythm and pitch are analysed by the left hemisphere, which is logical; it interacts with Broca's aria ${ }^{2}$, with the language area, which is able to recognize musical syntax. (Scaglioso, 2008, p. 227) (Montinaro, 2010, p. 50)

\section{The effects of music on the brain}

\subsection{Psychoacoustics, neurotransmitters and music}

Music has physiological effects on the brain and naturally on the whole organism. Research in the field of psychoacoustics, a branch of psychophysics that studies the relationship between the physical characteristics of a sound stimulus and the psychological effect produced, has revealed that listening to music triggers the production of neurotransmitters in the body, including endorphin, dopamine and serotonin. Neurotransmitters, which are chemical mediators located in the nervous system, facilitate the transmission, modulation and amplification, in synapses ${ }^{3}$, of nerve impulses coordinating communication between glands, organs and muscles in the body. "As far as we can tell, each brain center generates impulses at a specific frequency based on the predominant neurotransmitter it secretes. In other words, the brain's internal communication system - its language, if you like - is based on frequency." (Capel, Pinnock, Withey et al., 1982) For example, if the brain is induced alpha brain waves (frequency between 8 and $14 \mathrm{~Hz}$ ) or is in the Alpha state, they will generate a waking but relaxed state of consciousness, of calm and responsive mind, by producing endorphins and serotonin. The technology of synchronization of cerebral hemispheres - Binaural Beats - relies on this brain response; it is applied under the name of Hemi-Sync audio technology by

\footnotetext{
${ }^{2}$ Wernicke's area, along with Broca's area, are considered the seat of the motor and auditory images of words.

${ }^{3}$ The synapse is the contact area between two neurons.
} 
mixing the frequencies of brain waves with music, sounds from nature, verbal guides; the result is Metamusic, used to induce certain brain frequencies to the brain. "This acoustic alchemy put into practice has yielded significant results in the exploration of expanded consciousness states, creative capability development, learning processes acceleration, learning disabilities, focus and concentration, wellness, pain relief, anxiety and depression amelioration, as well as in improved sleep, hypnosis induction, meditation and relaxation." (Filimon, 2010, p. 108)

When listening to our favourite music - be it classical, pop, jazz, rock, New Age - the musical piece effects a state of relaxation that helps to remove fatigue and stress because the brain triggers the production of endorphins, serotonin and dopamine. The effects of endorphin, natural opioid substances, are analgesic, sedative, similar to those of morphine (Noback, 2005, p. 280). They have the role of relieving pain, of reducing stress and anxiety. The limbic system - the centre of emotions - contains a number of opioid receptors that are sensitive in the presence of endorphin-like chemicals. The beneficial effect of music, due to the release of endorphins in the body, causes emotional reactions biologically reflected by lower pulse rate, blood pressure and body temperature, decreased level of corticosteroids and adrenaline (stress hormones, which disrupt the balance of the human body), slower metabolism and improved body coordination. In addition to music, the internal secretion of endorphin is also determined by other stimuli, such as dancing, sports, meditation, laughter, sun exposure, spicy foods, sugar (especially chocolate). 'Endorphins have been invoked as 'music hormones' due to their 'morphine-like' action (an analgesic and euphoric effect), especially since for many listeners, music constitutes a source of euphoria, going up to ecstasy." (Luban-Plozza, Iamandescu, 1997, p. 81) Low serotonin levels cause mental disorders, depression, sleep disorders, while a decrease in dopamine leads to Parkinson's disease, ADHD disease; its excess causing addiction. Dopaminemediated neural links amplify positive emotions, inhibit unpleasant emotional signals, increase vitality and well-being (Salimpoor, Benovoy, Larcher, 2011).

\subsection{Neuroplasticity in the presence of music}

A physiological effect determined by listening and studying music results is the structural changes that occur at brain level. This process, called neuroplasticity (brain plasticity), is the result of the brain's ability to reconfigure its activity and structure in the presence of certain stimuli. This breakthrough in the field of neurology is mainly used for two purposes: prophylactic - neuroprotection, in the case of healthy people: augmentation of intellectual capacity, prevention of neurological diseases - and therapeutic - 
neuroregeneration and neurorehabilitation, in the case of patients who have undergone traumatic, inflammatory, degenerative processes of the brain.

Using the voxel-by-voxel morphometric technique, structural brain changes and adaptations have been observed in professional musicians who learn complex auditory and motor skills at an early age. Musicians develop skills in performing complex physical and mental operations, such as translating musical visual symbols from the score, performing sequential finger movements, improvisation, memorizing long musical phrases, identifying sounds without using a reference sound due to brain adaptations, but they also have innate abilities. Playing an instrument requires performance monitoring by simultaneously integrating multimodular, sensory and motor information with multimodular sensory feedback mechanisms. Compared to amateurs and non-musicians, pianists present significant structural cerebral adaptations of the grey matter and corpus callosum due to the bilateral activation of parietal areas corresponding to cerebral areas responsible for motor, auditory and visualspatial perceptions. In the case of amateur musicians an intermediate increase is signalled (Gaser, Schlaug, 2003). Reading musical scores activates an area of the brain located in the occipital cortex; this happens only in the case of this complex activity that requires knowledge of decoding sound material (Nakada, Fujii, Suzuki et al, 1998).

Instrumental musicians are often forced to perform two activities simultaneously, which stimulates both cerebral hemispheres: reading the score and implicitly the musical symbols involves the use of the left hemisphere, and the interpretation of the notes on the respective instrument requires the activity of the right hemisphere. Musicians who have studied an instrument that requires the independent use of both hands - piano, string instruments, wind instruments - have the ability to simultaneously use both cerebral hemispheres; this fact makes cognitive tasks easier to perform (Gibson, Folley, Park, 2009).

The activation of auditory sensory cortical areas results in the development of learning abilities, improvement of cognitive abilities, especially in the case of musicians. Learning music develops specific brain areas responsible for its decoding and integration function, and the younger the person, the more neural circuits are activated. Listening to cheerful or sad, exhilarating or relaxing music, changes in the vegetative nervous system are observed that cause the regulation of blood pressure, of heart rate, breathing and of other physiological reactions. Musical pieces with dance rhythm trigger somatic responses of the motor type causing involuntary movements movements of the upper and lower limbs, swing of the shoulders and trunk -, in the rhythm of music generating a relaxation of the body, felt as a relief of nervous tension. 


\section{Neurological trauma, physical disability and musical creativity}

Pathological changes at brain level have consequences in perception and influence all human activities. Disease alters the artistic creativity of people suffering from various pathologies, and its influence on art is a topic often addressed by researchers. People perceive psychosomatic suffering differently, therefore the expression of pathological and emotional states arising from it is different.

The design and creation of an artistic piece depends, among other multiple factors - genetic, psychological, educational - on pathological abnormalities. The artists translate their own sensory experiences and their own experiences into their works; sometimes this is amplified by nervous hypersensitivity and the suffering caused by their own pathology. Artistic perception and creativity are influenced by brain lesions of the brain. Obviously "it is extremely important that the clinical latency of psychosis disorders - that is the absence of patent clinical symptoms, diagnosable even by the entourage - resulted in the 'preclinical' behavioural manifestations of some composers being overlooked; however, the latent psychotic background could not fail to permeate the musical creation of composers such as Hugo Wolf and Robert Schumann, both suffering from manic-depressive psychosis." (Luban-Plozza, Iamandescu, 1997, p. 103) Biographies of many artists prove that neurological diseases influenced their artistic activity. Post-traumatic pieces are structured according to their creators' genuine experiences. Some of them are Johann Sebastian Bach, Georg Friedrich Händel, Domenico Scarlatti, Christoph Gluck, Joseph Haydn, Felix Mendelssohn Bartholdy, Henri Vieuxtemps, Hans von Bülow, Richard Strauss, George Enescu, Serghei Prokofiev, Benjamin Britten, Oscar Peterson (Zagvazdin, 2015, p. 150) (Mazzucchi, Fanticini, Bellocchio et al., 2017).

\subsection{Maurice Ravel}

In the last period of his life Maurice Ravel (1875-1937) revealed a progressive degradation of brain functions that began with difficulties in playing the piano, speaking and writing (1927). The neurodegenerative disease was manifested as motor and language disorders, partial memory loss, depressive states; the composer was diagnosed with Progressive Primary Aphasia (PPA) and apraxia (Seeley, Matthews, Crawford et al., 2008, p. 40) (Mazzucchi, Fanticini, Bellocchio et al., 2017).

His altered state of health did not prevent him from continuing to compose; he heard the music in his mind, as the composer declared (Orenstein, 2003, p. 319). A series of pieces composed after the onset of cerebral disorder approached classical structures, simplified: Boléro $(1928)^{4}$, Concerto for piano

\footnotetext{
${ }^{4}$ Boléro by Ravel, a ballet commissioned by Russian actress and dancer Ida Rubinstein.
} 
and orchestra in G major (1928-1931), Concerto for left hand (1929-1930), Don Quichotte à Dulcinée for voice and piano (1932). A mathematical analysis of two of his last pieces, Boléro and the Piano concerto for the left hand ${ }^{5}$, has revealed that neurological suffering changed the composer's musical style: the use mainly of woodwind instruments resulted in the metal-like timbre of the orchestra, the significant presence rhythm, the obsessive repetition of the same musical themes; this indicates damage to the left hemisphere, and the predominance of the right hemisphere in the process of creation (Amaducci, Grassi, Boller, 2002, pp. 75-82). Ravel described the Boléro as an orchestral fabric without music (Shaw, p. 5) .

The composer's health is irreversibly deteriorated, after he suffers various concussions in an accident involving the taxi he was in (1932). Ravel suffers a concussion with loss of consciousness, a chest injury, facial injuries and broken teeth. The various symptoms lead to a diagnosis of progressive sensory Wernicke aphasia and Pick's disease ${ }^{6}$. Following the accident, the depressive state he had been suffering from since 1927 deepens, and in the last years of his life he was unable to compose, conduct, play the piano and express himself verbally. "I will never write my Jeanne d'Arc; this opera is here, in my head, I hear it, but I will never write it. It's over, I can no longer write my music." (Vitturi, Sanvito, 2019, p. 137) Ravel died in 1937, following an unsuccessful trepanation operation by neurosurgeon Clovis Vincent (Luban-Plozza, Iamandescu, 1997, pp. 115-116).

\subsection{Paul Wittgenstein}

Ravel composed the Concerto pour la main gauche [Concerto for the left hand] at the request of the Viennese pianist Paul Wittgenstein (1887-1961), who lost his right arm in the World War One. The absolute premiere of the concert took place on January $5^{\text {th }}$, 1932, in Vienna, with Paul Wittgenstein as pianist, accompanied by Wiener Symphoniker [Vienna Symphony Orchestra] conductor Robert Heger. The lack of a vast piano repertoire dedicated only to the left hand leads Wittgenstein to commission works by other contemporary composers to allow him to continue his career as a solo pianist, among them Benjamin Britten, Paul Hindemith, Sergei Prokofiev, Richard Strauss.

The pianist's physical disability did not prevent him from pursuing his career as a performer and piano teacher; the presence, in the case of Wittgenstein, of the phantom limb symptom was a fact also contributed: at the cerebral level the lost limb is perceived as present, but paralyzed. This phenomenon, present in most people with amputated limbs, is triggered by the presence at brain level of nerve circuits associated with pre-existing innate

${ }^{5}$ Concert in one part, lento-veloce-lento.

${ }^{6}$ Fronto-temporal dementia, similar to Alzheimer's disease. 
motor schemes, such as the nerve matrix responsible for coordinating the movement of the fingers. The memory of the lost segment, a neural representation of motor sensory perceptions that persist at the brain level is added to the facts mentioned above. Thus, patients continue to perform phantom movements, initially considered to be only psychic hallucinations. One of Wittgenstein's students, Erna Otten, relates: "He often told me to trust his choice of fingering, because he felt every finger of his right hand. Sometimes he would ask me to sit still, close his eyes, and his stump would move agitated, continuously." Due to the need to adapt only for the left hand piano pieces intended for both hands and to be able to perform his own compositions for the left hand, Wittgenstein innovates the piano technique. He changes the fingering, pedalling, arm movements to be able to easily interpret difficult passages with one hand. His creativeness and special piano experience, both as a pianist and teacher, is packed in the three volumes published by Wittgenstein - Volume 1: Technical exercises, Volume 2: Studies, Volume 3: Transcriptions - under the name Schule für die linke Hand [School for the left hand] (1957).

\subsection{Vis arion Shebalin}

Russian composer and teacher Vissarion Yakovlevich Shebalin (19021963), one of the most acclaimed composers of his generation, studied composition with Nikolai Myaskovsky (1923-1928) at the Moscow Conservatory, where he became Professor of composition (1935) and then director (1942-1948). He composed various musical genres: operas, symphonies, string quartets, trios, choral music, romances, folk songs, film music. Along with Shostakovich, Prokofiev and Myaskovsky (1948), he was accused of decadent formalism and dismissed from the Moscow Conservatory.

Shebalin suffered from a first stroke $(\mathrm{CVA})^{7}$ in the left hemisphere of the brain at the age of 51 (1953), after a long period of hypertension. Paresis on the right side led to impaired speech and loss of control over the right arm, thus the composer was forced to write his scores and conduct with his left arm. Complete recovery occurs within a few months, and Shebalin continued composing and completed a number of works (orchestral, chamber music, music for film), and an opera in four acts, widely regarded as the most successful Russian opera whose libretto (written by Russian musicologist Abram Akimovich Gozenpud) is based on a play by one of William Shakespeare's works: the opera buffa Ukroshcheniye stroptivoy [The Taming of the Shrew], Op. 46 (premiere at the Bolshoi Theater). After the second

\footnotetext{
7 Cerebral vascular attack (CVA), also known as apoplexy, cerebral ischemia, cerebral infarction, cerebral haemorrhage; devastating disease caused by occlusion or rupture of cerebral blood vessels has an impact on physical and cognitive abilities.
} 
stroke (1959) he was diagnosed with aphasia, so he lost the ability to speak and understand what was spoken to him. However, his artistic abilities were preserved and he continued to compose a large number of pieces including: Quartet in C minor, Op. 53, No. 8 (1960), In the Land of the Mordves, Op. 5: Three songs for voice and piano (1961), Symphony No. 5 in C major, Op. 56 (1962), Quartet in B minor, Op. 58, No. 9 (1963), In the Forest Clearing, Op. 59: Seven children's choirs (1963). Shostakovich stated about his last symphony that, is a brilliant creative work, filled with the highest emotions, optimistic and full of life. The symphony composed during his illness is a creation of a great master" (Bogousslavsky, Boller, 2005, p. 175) (Trimble, 2006, p. 125). The Symphony is distinguished from previous symphonic creations by abandoning the formalism imposed by the social and cultural requisites of his time, by the vivacity and romantic optimism of the musical discourse; this piece reflects the composer's freedom of creative expression.

\subsection{Alfred Schnittke}

Alfred Garrievich Schnittke (1934-1998), a Russian-German postmodernist composer, teacher, an outstanding innovator of the musical language of the twentieth century, is another artist whose spiritual suffering and neurological disorders affected his compositional activity. He studied composition with Shebalin's teacher, Myaskovsky (1953-1958, Moscow Conservatory) and with Golubev (1958, Moscow Conservatory). As a student he was encouraged by Shebalin and Golubev to explore contemporary music. (Zagvazdin, 2015, p. 152) Throughout his life, through his creations and writings, Schnittke was concerned to translate his own thoughts and experience on human suffering, the salvation of the soul and of humanity, the confrontation between good and evil. For example, the reflection of the suffering caused by the loss of both parents was musically expressed in Requiem (19741975) and in the piece In Memoriam... (1977-1978) (Kholopova, 1989, p. 46).

During the $80 \mathrm{~s}$, he composed an impressive number of valuable works that would soon bring him national and international recognition, including: Symphony No. 2 "St. Florian” (1979), Symphony No. 3 (1981), Symphony No. 4 (1983), Gogol Suite (1980), Concerto No. 3 for violin and Chamber Orchestra (1978), Concerto for piano and Chamber Orchestra (1979), Passacaglia (1979-1980), Concerto No. 4 for violin and orchestra (1984), String Quartet No. 2 (1981), Concerto Grosso No. 2 (1981-1982), Concerto Grosso No. 3 (1985), The Faust Cantata (1983), Concerto for mixed choir (1984-1985), music for film - Malenkie tragedii [Little Tragedies] (1979), Ekipazh [The Crew] (1979), Skazka stranstviy [The Tale of Travels] (1982), Myortvye dushi [Dead Souls] (1984). However, his intense work exhausts his mental and physical capacities so that he suffers a first stroke (1985) located in the left hemisphere. Schnittke lost consciousness and was diagnosed with right 
hemiplegia (paralysis) and aphasia. "In 1985 I have completed six long compositions during six months. I do not understand how I was able to do it... I had on impression that the time flew extremely fast and kept accelerating, and on the limit of this acceleration stroke hit me, and a new circle in my development began." (Kotykhov, 1999 in Zagvazdin, 2015, p. 154)

The composer recovers, under the supervision of neurosurgeon Alexander Potapov, and resumes his compositional activity. He completes Symphony No. 5 (Concerto grosso No. 4), The Peer Gynt Ballet, Concerto No. 1 and No. 2 for cello and orchestra, Viola Concerto, String Quartet No. 4, piano sonatas. Alfred Schnittke reports: "after suffering a stroke, I realized that I remember considerably fewer things than before, yet I know much more. I began to find my bearings less by intellectual knowledge, rather by an animal instinct. I know something and can explain it, I can also find arguments (as a rule, I do find them), but I am no longer obsessed with their presence or absence. I know it anyway, although no one has explained anything to me. Before, I had to remember, then to think about how to answer correctly. [...] I feel that everything in history is infinite and nothing has any quality or final definition. But from every present point of view it seems to us that now, at last, some kind of clarity has emerged, but 70 more years pass and absolutely everything changes and what has long, it seems, ceased to exist returns" (Ivașkin, 1994 in Cosmescu, Ștefăneț, 2020, p. 22).

The second stroke (1991) catches Schnittke as he was conversing with his friend, film director Andrei Khrzhanovsky ${ }^{8}$, to whom he was talking about violinist Oleg Kagan. He mentions a strong headache that actually foreshadowed an attack that was located in the cerebellum. He becomes a permanent resident in Hamburg (1991), together with his wife, pianist Irina Schnittke and their son, Andrei". "Another thing I feel, an entirely subjective feeling, is about communicating with my son. I've long noticed a barrier between generations. We still represent the intellectual direction - the generation with brain skills, where everything is weighed, appraised. [...] I hardly ask him anything - he already has the answer ready, although he never talked about it or thought about it. It follows that there is knowledge without learning, too, and this knowledge is not of literary origin." (Ivașkin, 1994 in Cosmescu, Ștefăneț, 2020, p. 22) In Hamburg he taught composition (1991-1994) and was employed at the Hochschule für Musik. As with the first stroke, he recovers and continues to compose - Concerto Grosso No. 6 (1993), Symphony No. 6 (1992), Symphony

\footnotetext{
${ }^{8}$ Khrzhanovsky is the author of the animation film Glass Harmonica (1968), whose soundtrack was composed by Schnittke.

9 Andrei Schnittke (1965-2020), a bass guitar player in the rock band Tsentr [Centre] (1982-1984), composer, photographer. He collaborated with his father on the Faust Cantata (1983), on the music for the films The End of St. Petersburg (1992), The Master and Marguerite (1994). (Schmelz, 2021, pp. 184-187)
} 
No. 7 (1993). He dedicates The Piano Trio (1992) to the neurosurgeon Alexander Potapov, who helped him in his medical rehabilitation after his brain attacks. The post-lesion compositions reflect a departure from the extroverted multi-faceted style that established him and he moves towards an introspective compositional expression.

After the completion of Symphony No. 8 (1994) he suffers the third stroke. By this time, the attack occurs with consequences: after the coma, which lasted for three months, he was diagnosed with left side paralysis, aphasia and agraphia (major difficulties in speaking), no signs of amusia, which allows Schnittke to continue composing using his left hand to write with. All this greatly reduced his ability to compose. He starts composing Symphony No. 9, but the next stroke (1998) wreaks havoc on his brain; the composer died during the same year.

\section{The effect of Covid-19 on mental health and music therapy}

The rapid spread of the viral respiratory syndrome caused by the SARS-CoV-2 virus (Covid-19 - abbreviation from English - coronavirus disease 2019), after a first outbreak in Wuhan (China, December 2019), took all mankind by surprise. Declared a pandemic on March 11, 2020, by the World Health Organization (WHO), the contamination with the new virus has so far (March 2021) covered over 200 countries, infected 130 million people and caused 2.8 million deaths (WHO). In order to slow down and eradicate the community spread of the virus, since the onset of the pandemic, measures have been taken to prevent the infection - physical distancing of at least $1.5 \mathrm{~m}$, covering the mouth and nose with protective mask, special hygiene and hand disinfection -, the isolation of the population by instituting quarantine (lockdown) and currently the voluntary and free vaccination campaign against Covid-19 (starting December 2020).

We all feel the impact of the pandemic on our personal and professional lives. Fear of contamination, stress resulting from compliance with measures to prevent the disease, illness and even their loss of those close to us, isolation, lack of human communication, loss of jobs, drastic reduction of recreation opportunities, travel restrictions, change of lifestyle have generated feelings of helplessness, panic, anxiety, depression affecting both mental and physical health.

In spite of all the efforts and restrictions imposed by the authorities, new infections are counted daily, and the pandemic is still rampant. Social distancing measures have dramatically affected the people's daily lives of all as well as economic sectors due to closure of activity. The cultural and creative sectors, the service industry sector, the tourism sector, have been worst affected. The closure of art institutions, the cancellation of cultural events - concerts, tours, festivals, have affected artists, but also auxiliary 
staff. The disruption of pre-school, school and university education by the total or partial closure of educational institutions has required the reconfiguration of distance teaching activities through teleworking. Culture and education have continued to manifest themselves thanks to emerging technologies and accelerated digitalization, through online or asynchronous activities, contributing to the development of methodologies and technological solutions for distance learning and experimentation of new artistic forms with digital media access. Music during the Covid-19 pandemic has been successfully used in online environments to cope with the stress of social distancing and isolation, with people everywhere having the opportunity to express themselves artistically or to be spectators of novel cultural experiences.

The harmful effects of the current pandemic on the brain are obvious and are already reported in completed or ongoing research studies. The damage caused by the attack of the central nervous system by the Covid-19 virus or the mental damage generated by the new stressful living conditions, have led the specialists to request urgent psychological and psychiatric intervention. In the current pandemic context, mental health care is becoming a priority for the affected people employed in the highly strained medical system, of Covid-19 patients, as well as the entire population. Among the measures of rapid intervention an important role is played by music therapy, as a real instrument used to improve, treat and help recovery. Accrediting music as a therapy is supported by extensive research that has proven the beneficial effects of music on somatic health: it improves the immune system and mental health, it stimulates the production of neurotransmitters that induce well-being, reduce pain, stress, anxiety, depression (Chanda, Levitin, 2013).

Medical studies conducted during this period of health crisis have used neurological music therapy, monitoring the impact of music in improving and treating nervous system damage in medical professionals and Covid-19 patients or other people affected by anxiety and depression, the results being beneficial. For example, the medical staff of Covid-19 patients (University Hospital in Bari, Italy, from April 1 to May 6, 2020) had monitored fatigue, sadness, fear and worry, for 5 weeks. Under the influence of musical auditions coordinated by a specialist, the analyzed parameter values were lower. Sadness and worry were significantly reduced, as early as the first week. (Giordano, Scarlata, Baroni, 2020)

In the current pandemic context the importance of music therapy is enhanced by new clinical uses with immediate positive effects. A non-invasive, remedy within everyone's reach, music brings relief to the emotional, social, spiritual and physical trauma caused by the new coronavirus. 


\section{Conclusions}

The brain coordinates the whole organism, processes and stores the information transmitted by the sense organs. The process of music reception was initially attributed to the right hemisphere and it was considered that the left hemisphere is activated by language, but with the help of neuroimaging it was shown that the elements of the musical language activate various brain areas in both hemispheres, simultaneously generating the perception of music and emotions.

Music has physiological effects on the brain and on the whole organism. Hearing music triggers the production of neurotransmitters, including endorphin, dopamine and serotonin. When we listen to our favourite music the brain triggers the production of endorphins, natural opioid substances, which help relieve pain, reduce stress and anxiety. Listening to and studying music produce structural changes that occur at brain level due to brain neuroplasticity. The activation of auditory sensory cortical areas results in the development of learning abilities, improvement of cognitive abilities, especially in the case of musicians.

Neurological disorders and suffering modify the artistic creativity of people suffering from various pathologies. The artists translate their own sensory experiences and their own experiences into their works; sometimes this is amplified by nervous hypersensitivity and the suffering caused by their own pathology. Those who suffer from damage to the left hemisphere retain their musical skills: reading and writing scores, the ability to compose, which proves that musical skills are coordinated by the right hemisphere (if this has not been affected). Pieces composed at post-traumatic stages are structured according to their creators' genuine experiences.

Decoding the functioning of the brain in the presence of music and its effects on brain activity make it possible to use music therapy as a complementary method to medical treatment, an alternative to drug treatment that often come with negative side effects and high costs. The harmful effects of the current pandemic on the brain are obvious and are already reported in completed or ongoing research studies. In the current pandemic context, the care of the mental health of those mentally affected, especially medical staff and Covid-19 patients, is becoming a priority. Among the measures of rapid intervention an important role is played by music therapy, as an instrument used to improve, treat and help recovery for persons in difficulty.

The adoption of music as a therapeutic tool in the current global epidemiological crisis highlights its undeniable qualities in multiple pathologies and updates its mental and somatic benefits, complementary to medicine. All this provides an important drive in the reassessment and reconfiguration of the need to amplify the interference strategies between the field of music and that of medicine, implicitly that of neurology. 


\section{References}

Amaducci, L., Grassi, E., Boller, F. (2002). Maurice ravel and right-hemisphere musical creativity: Influence of disease on his last musical works? European Journal of Neurology, 9 (1), 75-82.

Beaumont, G.J. (2008). Introduction to Neuropsychology, Second Edition. New York: The Guilford Press.

Blood, A. J., Zatorre, R. J. (2001). Intensely pleasurable responses to music correlate with activity in brain regions implicated in reward and emotion. Proceedings of the National Academy of Science, 98, 11818-11823.

Bogousslavsky, J., Boller, F. (2005). Neurological disorders in famous artists, 19. Basel, Switzerland: Karger.

Capel I. D., Pinnock M. H., Withey, N.J, Williams, D.C., Patterson, M.A. (1982). The effect of electrostimulation on barbiturate-induced sleeping times in rats. Drug Development Research, 2, 73-79.

Cosmescu, A., Ștefăneț, V. (2020). Alfred Schnittke despre „cultura a patra” și trecerea de la cunoașterea intelectuală la cea intuitivă. Compozitori ai secolului XX, [Alfred Schnittke on the "Fourth Culture" and the Transition from Intellectual to Intuitive Knowledge. 20th Century Composers]. Contrafort, 4 (296), 22-23. Chișinău.

Daly, I., Williams, D., Hwang, F., Kirke, A., Miranda, E. R., Nasuto, S. J. (2019). Electroencephalography reflects the activity of sub-cortical brain regions during approach-withdrawal behaviour while listening to music. Scientific Reports, 9 (1), 9415.

Ferreri, L., Mas-Herrero, E., Zatorre, R.J., Ripollés, P., Gomez-Andres, A., Alicart, H., Olivé, G., Marco-Pallarés, J., Antonijoan, R. M., Valle, M., R., Jordi, RodriguezFornells, A. (2019). Dopamine modulates the reward experiences elicited by music. Proceedings of the National Academy of Sciences of the United States of America, 116, 9, 3793-3798.

Ferrey, G. (1995). Abord psychosomatique des traumatisés crâniens. Paris: Masson Publisher.

Filimon, R. C. (2010). Beneficial subliminal music. Binaural Beats, Hemi-Sync and Metamusic, Recent Advances in Acoustics \& Music, Proceedings of the 11th WSEAS International Conference on ACOUSTICS \& MUSIC: Theory \& Applications AMTA'10, 103-108.

Gaser, Ch., Schlaug, G. (2003). Brain structures differ between musicians and nonmusicians. Journal of Neuroscience, 23 (27), 9240-9245.

Gaspar, V. (2002). Repere spaţiale şi semantice în receptarea muzicală [Spatial and semantic landmarks in music reception]. București: Editura Muzicală. 
Gibson, C., Folley B. S., Park S., (2009). Enhanced divergent thinking and creativity in musicians: A behavioral and near-infrared spectroscopy study, Brain and Cognition, 69 (1), 162-169. Elsevier.

Giordano, F., Scarlata, E., Baroni, M., Gentile E., Puntillo, F., Brienza, N., Gesualdo, L. (2020). Receptive Music Therapy to reduce stress and improve wellbeing in Italian Clinical Staff involved in COVID-19 Pandemic: a preliminary study, The Arts in Psychotherapy. Elsevier.

Harding, E., Sammler D., Henry M. J., Large E. W., Kotz S. A. (2019). Cortical tracking of nested beat structure in music and speech. Neuroimage, 185, 96-101.

Kholopova V. (1989). Per aspera ad astra. Soviet life, 45-47.

Levitin, D. J. (2010). Creierul nostru muzical. Știința unei eterne obsesii Our musical brain [The science of an eternal obsession]. București: Editura Humanitas.

Levitin, D. J., Chanda, L. (2013). The neurochemistry of music. Trends in Cognitive Sciences, 17 (4), 179-193.

Luban-Plozza, B., Iamandescu, I. B. (1997). Dimensiunile psihologice ale muzicii. Introducere in muzicoterapie [The psychological dimensions of music. Introduction to music therapy]. Bucureşti: Editura Romcartexim.

Manzelli, Paolo, Cervello e Memoria, 2. Cervello e Musica. Retrieved from: http://www.storiologia.it/cervello/cerv01.htm

Marini, M. G. (2018). Languages of Care in Narrative Medicine. Words, Space and Time in the Healthcare Ecosystem. Springer International Publishing.

Matschke, J., Lütgehetmann, M., Hagel, Ch., Sperhake, J. P., Schröder, A. S., Edler, C., Mushumba, H., Fitzek, A., Allweiss, L., Dandri, M., Dottermusch, M., Heinemann, A., Pfefferle, S., Schwabenland, M., Magruder, D. S., Bonn, S., Prinz, M., Gerloff, Ch., Püschel, K., Krasemann, S., Aepfelbacher, M., Glatzel, M. (2020). Neuropathology of patients with COVID-19 in Germany: a post-mortem case series. The Lancet Neurology, DOI: https://doi.org/10.1016/S1474-4422(20)30308-2

Mazzucchi, A., Fanticini, F., Bellocchio, M. G., Petracchi, D., Boller, F. (2017). The Influence of Brain Lesion on Musical Masterpieces of Famous Composers. Journal of Neurology and Neuroscience, 8 (6), 236.

Montinaro, A. (2010). La musica neurologica: Dal mito alla scienza e viceversa. Varese: Zecchini Editore.

Nakada, T., Fujii, Y., Suzuki, K., Kwee, I. L. (1998). Musical brain revealed by highfield (3 Tesla) functional MRI. NeuroReport, 9 (17), 3853-3856.

Orenstein A., (2003). A Ravel Reader: Correspondence, Articles, Interviews. New York: Dover Publication.

Pearce, J. M. S. (2019). The "split brain" and Roger Wolcott Sperry (1913-1994), Revue Neurologique, 175 (4), 217-220. 
Pucarin-Cvetković, J., Zuskin, E., Mustajbegović, J., Janev-Holcer, N., Rudan P., Milosević, M. (2011). Known Symptoms and Diseases of a Number of Classical European Composers during 17th and 20th Century in Relation with their Artistic Musical Expressions. Collegium Antropologicum, Journal of the Croatian Anthropological Society, 35 (4), 1327-1331.

Raglio, A., Attardo, L., Gontero, G., Rollino, S., Groppo, E., Granieri E. (2015). Effects of music and music therapy on mood in neurological patients. World Journal of Psychiatry, 5 (1), 68-78.

Ramachandran, V. S., Hirstein W. (1999). The Science of Art: A Neurological Theory of Aesthetic Experience. Journal of Consciousness Studies, 6 (6-7), 15-51.

Rouse, M. H. (2019). Neuroanatomy for Speech-Language Pathology and Audiology, Second Edition. Burlington, Massachusetts: Jones \& Bartlett Learning.

Sacks, O. (2009). Muzicofilia. Povestiri despre muzică şi creier [Musicophilia: Tales of Music and the Brain]. București: Editura Humanitas.

Salimpoor, V. N., Benovoy, M., Larcher, K., Dagher, A., Zatorre, R. J. (2011). Anatomically distinct dopamine release during anticipation and experience of peak emotion to music. Nature Neuroscience, 14, 257-262.

Scaglioso C. M. (2008). Suonare come parlare: linguaggi e neuroscienze, implicazioni pedagogiche [Playing as speaking: languages and neuroscience, pedagogical implications]. Roma: Armando Editore.

Schmelz, P. J. (2021). Sonic Overload: Alfred Schnittke, Valentin Silvestrov, and Polystylism in the Late USSR. New York: Oxford University Press, 1st edition.

Seeley W. W., Matthews B. R., Crawford R. K., Gorno-Tempini, M. L., Foti, D., Mackenzie, I. R., Miller, B. L. (2008). Unravelling Boléro: progressive aphasia, transmodal creativity and the right posterior neocortex. Brain, a Journal of Neurology, Oxford University Press, 131 (1), 39-49.

Seguelman, M. (2005). Vissarion Shebalin (1902-1963). His life and work. Moscova: Le chant du monde.

Shaw, P. (2008). Ravel's Boléro Factory: The Orchestration of the Machine Age. Context, 33, 5-23.

Shreeve J. (2005). Dincolo de creier [Beyond the brain], National Geographic Revue, 18-47, București.

Sloboda, J. A. (1985). Composition and improvisation. In the musical mind. The cognitive psychology of music, UK, 102-150. Oxford Science Publications.

Tramo, M. J. (2009). Split-brain studies of music perception and cognition. Contemporary Music Review, 9 (1-2), 113-121, Routledge.

Vitturi, B., Sanvito, W. L. (2019). Maurice Ravel's dementia: the silence of a genius. Art and Neurology, Neuro-Psiquiatria, 77 (2), 136-138.

World Health Organization, https://www.who.int/ 
Zagvazdin, Y. (2015). Stroke, music, and creative output: Alfred Schnittke and other composers. Progress in Brain Research, 216. In Altenmuller E, Finger S, Boller, F. Music, Neurology and Neurosciences. Historical Connections and Perspectives, 7, 149-165.

Zatorre, R. J., Perry, D. W., Becket, C.A., Westbur, C.F, Evan, A. C. (1998). Functional anatomy of musical processing in listeners with absolute pitch and relative pitch. Proceedings of the National Academy of Sciences of the USA, 95, 3172-3177. 